\title{
The Transnational Governance of Ecuadorian Migration through Co-Development
}

\author{
Almudena Cortés Maisonave*
}

\begin{abstract}
The purpose of this paper is to show the relationship between co-development projects with transnational interests and the governance of migration by the Spanish and Ecuadorian governments. On one hand, the emergence of co-development is linked with the political dimension of migration, and therefore, with the challenges that its management poses for both the sending and receiving states. Simultaneously, the state exists in a context of the reconfiguration of its traditional functions, and above all, the manner in which it goes about performing them. For these reasons, co-development projects form part of state governance strategies, based on a special understanding of the nexus between migration and development in European social space, involving international organizations, state governments, and civil society, linked by migratory flows. This is demonstrated in the case of Ecuador and Spain. Since Spain stimulated co-development, the implementation of projects with Ecuador has been emphasized, due to the dimensions achieved by Ecuadorian migration. Co-development politics and projects are analyzed in this paper as areas of intervention integrated by values, guide lines and cultural understandings about migration, including appropriate forms of control and management.
\end{abstract}

\section{INTRODUCTION}

In September 2003, the Secretary of State for International Aid for Latin America (SECIPI) of the Spanish government organized a series of co-development meetings ${ }^{1}$ in order to fulfil "the policy mandate within foreign policy to explore in depth a co-development strategy". One of the participants in the afternoon sessions was the General Director for Aliens

* Social Anthropology Department, Universidad Autónoma de Madrid, Madrid. 
and Immigration (from the Ministry of the Interior), who began his talk with the question: "What is a member of the Ministry of the Interior doing talking about these matters?"2 The question was a logical one given that the audience for these meetings was composed of stakeholders from the field of development aid. The General Director participated in the round table entitled "Managing Migratory Flows; Interests and Proposals", and during his presentation at that session, he stated, "Co-development has to be tied to the control of flows, otherwise it wouldn't make sense". 3 This raises the question of why the Spanish government has deferred control of migratory flows to the field of development aid.

Current characteristics of migration, like transnational flows and processes, constitute a political challenge for receiving states, in relation to their sovereign capacity. Simultaneously, the state finds itself in a context of a reconfiguration of its traditional functions, and the way in which it may go about performing them. The emergence of immigration as a central question on the European political agenda consolidated itself throughout the 1990s, and has had a double effect: the "sensation of crisis" that immigration provokes (Brettell and Hollifield, 2000; Sassen, 2001), and the transformation of immigrant communities into influential political stakeholders who exert demands on administrative and democratic institutions of sheltering countries (López Sala, 2002: 89).

Transnational studies have devoted themselves to the analysis of the redefinition of the classic concept of the nation-state, as much in destination countries as in those of origin (Labelle, 2002; Levitt and Dehesa, 2003; Vertovec, 2001), and to the political activities of the immigrants with respect to their communities of origin (Vertovec, 2001; Sørensen and Fog, 2002, Østergaard 2003), and public politics and transnational migratory relationships centered in countries of origin (Levitt and Dehesa, 2003; Portes 2007). However, there have been very few studies to analyse the transnational significance of the thrust of co-development's public politics, namely, the politics that link migration and development in the framework of the governments' actions and public administrations in destination states (de Haas, 2006). In the last two decades the majority of European Union countries have implemented, to a greater or lesser extent, so-called co-development policies that attempt to relate migration with development (de Haas, 2006). In this sense, we can affirm that the receptive states have begun to form part of the transnational process in an active way by means of government intervention. The governments have provided a series of public politics, of lines of action and help, which try to influence the course of migration through 
transnational relations with migrants. We can see examples of this in the adoption of round measures for remittances, for returns, for productive projects and for the promotion of the associations of migrants in codevelopment projects. Nevertheless, transnational investigations on the meaning, stakeholders and practices of co-development as public policy impelled from the receiving countries do not exist. In this sense, and probably due to the context of emergence of co-development for the Spanish case, this usually is confused, with the transnational practices of migrant linked to development.

Thus, the migration and development studies in Spain can be classified in two types: those that have been dedicated to analyse the transnational practices of the migrant in relation to development, and those that are focused on the co-development in a broader sense.

The first group has centred its analysis in "emergent aspects" of the debate, such as the transnational practices that the migrant have impelled in connection with their contexts of origin (locality, country, region, etc.) and the relation that these maintain mainly with the development. Thus, for example it is common to find studies that talk about the role of the social and migratory networks (Pajares, 2007; Pedone, 2004), the role of the remittances in the development (Sanz 2007), the emergence of transnational identity processes (Eguren, 2004, 2007; Padilla and Moraes, 2007) or the gender impact in the development (Martin et al., 2008).

In the same way, it is necessary to emphasize, that the reflection on migration and development, has been linked to specific geographic areas, as it is the case of Morocco (Lacomba, 2002, 2004), sub-Saharan Africa (Carballo and Echart, 2007), or the most recent case, the Andean Region (Cortés and Sanmartin, 2008; Cortés y Torres, 2009).

Regarding the studies focused on the co-development, these have addressed their analysis to several issues of interest. In general terms, most of the studies arisen in Spain, usually orients their analysis towards the newness of the term, in spite of existing a group of them dedicated already to analyse the praxis of the co-development in and from Spain (Giménez, 2005; Giménez et al., 2006; Cortés, 2004, 2005, 2006, 2009a,b; Cortés et al., 2007; Malgesini, 2007).

First of all, we found the essays and researches focused on understanding the relation between migration and development aid, more than to analyse the co-development itself (Abad, 2004, 2005, 2008; Gomez Gil, 
2008; Malgesini, 1998, 2001; Marin, 2004). In this sense, the central discussions have turned around if the co-development is a cooperation form, and/or how the migration can influence or not, in the development aid, and vice versa.

Secondly, there is a group, focused on the understanding of co-development as "policy", made up of a set of texts and pioneering reflections (Aubarell et al., 2003; Aubarell and Aragall, 2005; Ramón, 1999, 2002, 2005), as well as by technical reports and normative studies (Carballo, 2006; Olabarría, 2009). These essays have located the analysis of the co-development in the field of the European and local policies, and it is significant the lack of critical studies focused on the meaning of the Spanish policy of co-development. Finally, there are other studies centered on the key stakeholders in the co-development, the migrants (Echeverri et al., 2007; Sanmartin, 2009).

We can state, therefore, that there is an absence of essays, studies and other research that analyses, the political, social and cultural meaning of the practices of co-development in Spain from a transnational perspective.

In this article I explore and analyse, from a transnational perspective, the practice of co-development between Ecuador and Spain. "Codevelopment" refers to a set of actions, practices and public policies fostered by the Spanish state in the migratory context between Ecuador and Spain, which have taken shape through development projects. Both countries are united by a colonial past, and recently, their relationships have intensified starting with the increase in migratory flows, which has led both countries to increasingly establish projects of co-development with each other. The two countries also share a development relationship of donor and receiver, which allows contextualization of the previous cooperation relationships in which co-development has been introduced. Under this etiquette, the Spanish government has promoted a series of actions with Ecuador (although also with Morocco, Senegal and Colombia) in the sphere of migration and development, with the purpose of generating development in Ecuador.

My line of argument in this work stems from the idea that the emergence of co-development is related with the reconfiguration of the traditional tasks of the nation-state, but above all, with the new facets of government practice. Thus, the state realizes its functions in a concerted and cooperative way with other stakeholders, carrying out what can be considered as government "at distance" (Morris, 1998; Rose, 1997) 
(both social, and in this case, geographical distance). Instead of losing the role of protagonist, the state seeks to demonstrate and deploy its authority through the exercise of government patterns on problems of a transnational dimension, as is the case with migratory movements. For the purpose of broaching global issues with success, governance would acquire a special relevance, allowing the establishment and operation of a group of rules of conduct that define practices, assign functions, and incorporate national and transnational stakeholders, governmental and non-governmental, while guiding their interactions. In this sense, development cooperation would be being implemented as a route to introduce norms and guide lines of "good government" with respect to the migration "problem" through the area that connects migration with development. Referring to new "government patterns", it concerns the investigation of the new faces of governance concerning transnational issues, for which this work interprets governance as "the process of management of society resulting from the systematic collaboration between government and citizens, beginning with civic organizations" (Peró, 2005: 1). Peró continues that the term governance implies a superior government pattern, and contains a crucial meaning: that which allows the state to comply with modernity. According to this, we are witnessing a new allocation of responsibilities between government and civil society: the government is required to take strategic decisions and design objectives, while the provision of services and administration evidently falls back on citizens and their organizations (Peró, 2005: 2).

In the case which concerns us, the executing stakeholders of the practices of co-development will be as much NGOs as it will be migrant associations, in origin and in destination, which makes it necessary to understand the importance of particular institutions, movements and organizations as "brokers" or mediators of this process. For this reason, it is essential to address the way in which stakeholders of co-development promote this model from an intermediate space of socio-cultural action and politics, as much in origin countries as in those of destination, giving place to practices framed in transnationalism from the middle (Smith, 2005: 241). Following this author's concept we will understand a related term with respect to the mediation of social relationships of power-dominance-conform-resistance, among transnational stakeholders from above and below, bearing in mind that the categories of "above" and "below" are an attempt to capture the dynamics of relationships of power in the transnational arena. By definition, these categories are contextual and related more than essential and unalterable (Smith, 2001: 110-113). 
Because co-development is characterized by the articulation of the migratory contexts of exit and arrival, the research strategy applied has been, perforce, multi-situated (Marcus, 2001). Following transnational logic, I have taken, in a "continuous and fluid" fashion, the research field between Madrid and Ecuador; thus, in order to analyse these practices, it is necessary to take into account co-development practices and their impact on both countries.

To approach this analysis, I use a variety of qualitative sources, beginning with more than 100 detailed interviews with Spanish and Ecuadorian staff members of NGOs implementing projects, as well as leaders of Ecuadorian migrant associations tied to said projects, and Ecuadorian and Spanish government workers. The interviews are complemented by ethnographic data collected through participatory observation of the daily dynamics of co-development projects in various places (Pichincha, Azuay, Cañar and Loja in the Ecuadorian Sierra, Guayaquil on the Coast, and Madrid) and in diverse events and celebrations (internal work meetings, workshops, participation in political migrant events, meetings with Ecuadorian and Spanish politicians, etc.), both in Ecuador and in Madrid. At the same time, the ethnographic data is complemented with archive material, including official project documents, documents on the institutions involved, etc.

The research strategy has followed a method of extensive case studies that, tied to the theoretical discussion, attempt to relate observations at the micro-level and data from interviews with wider transnational and global forces, connections and imaginations through which the global and the local are connected (Burawoy, 2000) in the daily lives of the subjects of this investigation. For this reason, the ethnographic work presented here has required periods of intense field work in various phases throughout 2004, 2005 and 2007.

\section{TRANSNATIONAL RELATIONS OF MIGRATION AND DEVELOPMENT BETWEEN ECUADOR AND SPAIN: THE CHALLENGE FOR THE RECEIVING GOVERNMENT IN THE TRANSNATIONAL SPACE}

Co-development has become an instrument for channelling "new issues" and "new ways to approach them" in the field of migration and development. This proposal appears for the first time in a period of transition between a Spain of emigration and the creation of an "immigrant" 
Spain. This has implied a change in the geopolitical position carried out by Spain, and in the way in which Spain is related to the sending countries, which has influenced in the perspective from which is boarded the migration-development nexus. Thus, this perspective has been reduced to security issues, migration flows control, integration in the receiving society and handling of remittances (conceived like the main impellers of development).

While co-development has become part of the group of Spanish migratory policies, Ecuadorians have become the largest group of Latin American migrants. In 2002 Ecuador became the second largest provider of immigrants, only surpassed by Morocco. The figure rose from 3,972 registrations in 1998 to 259,779 in 2002, and to 487,239 in 2005 (INE, 2005). This implies a very significant flow (around 84,000 people per year) from 1999 to 2004, at which time an important decrease is perceptible due to the visa imposition starting in 2003.

All of this lends to Ecuadorian migrants a strategic importance for migratory policies. This has happened through the creation of policies and projects in the area of co-development and by way of links between these and a broad set of transnational practices carried out by Ecuadorian residents in Spain. Below, we present the most significant.

\section{The rise of a transnational associative movement}

One of the most significant areas of transnational relations carried out by Ecuadorian migrants from Spain has been the rise of a transnational associative movement with the clear objective of transnational political effect. The arrival of Ecuadorian migrants and their settlement in Spain takes place within a process, more medium and long range, of gradual conformation of transnational communities of Latin American migrants in countries in the South of Europe, structured through political action whose associative/organizational dimension as a network is fundamental (Kastoryano, 2000).

In the political transnational incidence established between Ecuador and Spain, two key processes have played a significant role: the emergence of a migrant transnational association, and the constitution of a migrant civil society as a result of co-development projects (although not exclusively) (Cortés, 2010). With respect to the first of these issues, 2001 constituted a landmark of big implications for Ecuadorian migration in Spain and in Ecuador for two reasons: first, was a dramatic accident in 
Lorca (Murcia), and second, the reform of Spanish migratory law and the ensuing threat of expulsion for migrants without papers. More precisely, on 9 January 2001, 12 Ecuadorian labourers died as they travelled in an overcrowded van that was trapped on train tracks in the Lorca area (Murcia). Until that moment, migration had been maintained outside of the political agenda in Ecuador, ${ }^{4}$ contrary to the Spanish context where the Hispanic-Ecuadorian Association Rumiñahui, created in 1997, had already begun to realize activities, not only the general attention to the Ecuadorian population (papers, work, housing), but also activities of a transnational character like the pressuring of the Ecuadorian congress to attain the external vote or the signing of the Agreement of "La Casa del Migrante de Quito" (Jokisch and Pribilsky, 2002: 89). The association was certainly much stronger in Spain than in Ecuador, but in thirty years of migratory history between Ecuador and the United States, the creation and invigoration of an associative movement of this calibre had not taken place.

For Spain, the incident achieved an extraordinary dimension for several reasons. Firstly, Aznar's second government had promoted reforms to immigration law, toward a much more restrictive model. Migrant groups perceived this with a lot of fear, and the threat of the expulsions had already begun to spread. Secondly, due to this issue, Spanish civil society sensitive to the migratory topic planned to instigate a series of "shut-ins" as a protest to the new immigration law. The said movement demanded the regularization of all the immigrants who lived in an irregular situation and had its epicentre in Murcia - later expanding to Barcelona, Madrid, Valencia, Almería and Melilla (Laubenthal, 2005: 159). Ecuadorians also participated in these movements in such a way that in some cases, they were mobilizations against the reform of the immigration law that served as the genesis of some associations.

As a result, a little time after the exit of Ecuadorian migrants to Spain, two of the most important migrant organizations emerged: Association Rumiñahui 9 de enero and Association Llactacaru, following the return of their leaders to Quito. They were recently created organizations that in many cases were characterized by their youth, lack of maturity, and lack of experience. But beyond this are two features that would characterize these associations: the transnational dimension of their political work, and their differentiation from NGOs. With respect to the first of these issues, these associations carried out a strategy of political incidence linked between both contexts, they understood that the fight for migrants rights was realized on a continuum, important as it was to 
achieve successes in Spain, this served for little if it was not accompanied by corresponding conquests in Ecuador. It was this which led relatives to be involved in this process: "[T]he need was the same, if the struggle was there (Spain) and there was no response here (Ecuador), who was promoting it, who was then working? We family members felt we had a direct responsibility" (Rumiñahui Association leader, Quito, 2004).

This continuous scene of struggles made it possible to take up and lend continuity to the processes of collective struggle for citizenship, and demands for fundamental rights in the places of origin, many of these urban, such as access to housing, health services, etc. These different traditions for demanding rights were now based on demands related to the struggle of migrants in Spain, and for the recognition of their rights. The stage had changed, but the struggles were similar. In this sense, Ecuadorian migration has turned into a field from which those involved have been able to maintain and deepen struggles born at the margins of migration, but which share a horizon of struggles and a number of organizational patterns.

One of the most significant cases that demonstrates how the migrant organizations tried to use the co-development in their emergence, in order to channel certain efforts of political incidence in the migratory scope, is La Casa del Migrante. This project started from the signature of the "Agreement of Collaboration among la alcaldía del Distrito Metropolitano de Quito, la Asociación Hispano Ecuatoriana Rumiñahui y el Movimiento por la Paz, el Desarme y la Libertad", ${ }^{6}$ in Madrid, on 24 May 2001. First of all, this project arose impelled by the urgency from the recent changes of migratory policy between Ecuador and Spain, due to the intensity and dimension that the Ecuadorian migration had reached between both countries.

Thus, the announcement of the regularization of migrants that took place in Spain at the beginning of 2001, coincided with the negotiation of the most important migratory Agreements between both countries: the Migratory Flows Agreement and the Return Agreement. In view of the expectancy triggered by the recruitment of Ecuadorian workers through the Technical Unit of Selection, an informal team was organized among la Casa del Migrante, the Rumiñahui 9 of January organization, and the Jesuit Service to Refugees and Migrants (SJRM) to offer monitoring and training to migrants through workshops about how to present the demanded documentation. ${ }^{7}$ 
Simultaneously, the Rumiñahui association offered an assessment to Ecuadorian migrants in order to prepare the demanded documentation for the extraordinary regularization in Madrid. The idea and the proposal of the creation of "la Casa" were born in Madrid from the initiative of the Rumiñahui organization. In view of the absence of responses that the Ecuadorian State was offering to their migrants, Rumiñahui addressed their claims to the local level of power. Over time, this organization negotiated, collaborated and came into conflict with the Quito City Council as a result of this project. The project began as a project of civil society, and turned into an institutional co-development project assumed and driven by the City Councils of Madrid and Quito.

Regarding the second of the main issues, one of the most important co-development fields, in both Spain and Ecuador, has been the institutional strengthening of the migrant organizations. In the Ecuadorian case, the migrant organizations and those formed by and for migrant relatives have been characterized by their organizational weakness and the internal divisions of the associative movement. For these reasons, the main task of certain NGOs has been to strengthen the migrant organizations.

NGOs provide support by receiving and managing public money, and deciding how to spend it. Thus, whereas co-development policies conferred the "dominant role" to migrants in fostering development, the discourse and practice of co-development still establishes migrants as "beneficiaries" in this way.

Although there are co-development projects that take the migrants organizations into account, it is difficult to state that these organizations are stakeholders at the same level as the NGOS. Rather, they are often invited to participate later, as it is the case of the project Remittances and Development (REDES), managed by the Union de Cooperativas Madrileñas de Trabajo Asociado (UCMTA), ${ }^{8}$ or the project of Save the Children from which the Network "Together, We are More" arose.

The exception in this sense has been the project of co-development of ACSUD and Intiñan, ${ }^{9}$ in which all the stakeholders have participated at the same level from the beginning: the NGO ACSUD, the migrant organization Intiñán, and the local partner, the Jatari Foundation: "the co-development requires time and resources. This is a consultative process, a democratic and participatory process of all actors. Without this procedure, it seems to me that it is not a co-development process, but 
rather a process of common development aid" (Jatari Foundation leader, Saraguro, Loja, 2007).

But how can organizations participate at the same level when there are important power asymmetries? In this context, the migrant organizations have developed the strategy of sharing the same project in order to keep their presence in the public sphere: "We are together but we are different from them in many things. For example, if there is a meeting, they can travel by plane every week, while we must travel all night in bus. Then it is quite difficult for us...there is an enormous difference among organizations..." (Rumiñahui 9 of January leader, Quito, 2007).

Although the migrant organizations hold an unequal position, it does not mean that they cannot influence in the decision-making of the co-development projects. They take part of these projects because they are searching for prestige, consolidating their position among other Ecuadorian migrants' organizations, increasing their network of contacts, and connecting themselves with organizations within the EU, among other things.

\section{The mobility of Ecuadorian migrants: recruiting labour and returning home}

The intense arrival of Ecuadorian migrants to Spain coincided with a deep reconfiguration of the Spanish migratory policy, which affected the way that Ecuadorian migration came to be understood as a "problem".

Under the new Spanish policy, the mobility of Ecuadorian migrants was at stake. One of the most important aims of the migratory policy was to develop strategies to tie the migrant population to their land of origin or to encourage them to return. Both options have been incorporated into co-development policies, and for this, co-development has sometimes been seen as synonymous with migratory control, return projects, or development aid in contexts of migration.

At the beginning of 2001, Spain and Ecuador signed the "Agreement between the Republic of Ecuador and the Kingdom of Spain Relative to the Regulation and Ordering of Migratory Flows", which was accompanied by other agreements on migratory matters including those establishing the unit for the selection of migrants eligible for participation in the Spanish labour market. In effect, one of the most important elements in the control of migratory flows is the selection and recruitment 
of Ecuadorian workers according to the needs of the Spanish labour market. While the letter of the accord granted broad functions to Ecuadorian authorities in managing the process of recruiting workers, contracting labour from the sending country includes a great deal of participation by the Spanish business sector. Both Ecuador and Spain took credit for the success of these measures. On the one hand, Spain presented the agreement as a measure intended to ensure that Ecuadorian labourers arrived in Spain with a work contract, and thereby, a successful way to manage labour flows. For its part, Ecuador presented the measure as an achievement for its foreign policy related to Ecuadorian emigrants, given that it was the first country in the region to negotiate such an agreement. The agreement achieved epic dimensions, with Ecuadorian workers from throughout the country appearing before the Technical Selection Unit in Quito. However, But it was a failure because "it was said that 30,000 to 40,000 Ecuadorians would leave with a work contract, but up to 2003, only 1,004 did so" (El Comercio, 17 June 2004).

The other side of migrant mobility is the return home. In the Ecuadorian case, paradoxically, the Voluntary Return Plan was signed on 31 March 2001, before the Migratory Flow Accord of 19 May 2001. Beginning with the former, Spain promised to assume the costs of return to Ecuador for migrants without papers. For that purpose, migrants had to sign up to participate in the plan and to have a pre-work contract emitted by the Spanish Embassy in Quito. But the number of those signing up was so great $(25,000)$ that it became impossible for the Spanish government to assume the costs. This led Spanish authorities to decide to legalize thousands of Ecuadorian without requiring that they return to Ecuador. That is, the agreement became in fact a concealed mechanism of regularization, rather than a return programme (Aja, 2006; Izquierdo, 2002).

The return home has been a constant concern in Ecuador since the beginning of the new migratory phase beginning in 1998-1999. The administrations of Lucio Gutiérrez and Alfredo Palacio addressed this issue, though with few results, and the current administration of President Correa has attempted the same through an evident attempt to renew national loyalty among Ecuadorian. This is also apparent in the launch of the Welcome Home Return Plan, promoted by Ecuador's National Secretariat for Migrants (SENAMI). The same concern is manifested by various Ecuadorian and Spanish DNGOs, through co-development projects: "And that's it, we train them, well, more than 
training, what we do is workshops on the migration issue, how to migrate legally, what happens if someone migrates illegally, what are the steps you have to take, what's going on with the voluntary return topic" (Aid Worker, CIDEAL, Quito, 2007).

We are witnessing a proliferation of discourses incorporating "new legal orthodoxies" (Santos and Rodríguez, 2007: 15), such as the right way to migrate (legal versus illegal migration) and return home, or different economic logics, as we will see below in the case of how remittances are used.

\section{The money from Ecuadorian migration: the remittances and savings of Ecuadorians}

Co-development projects have made the issue of remittances issue one of their core aspects; there has thus been a great proliferation of projects based on remittances, their management and the aim of channelling remittances towards productive initiatives. First, in general, there has been paradigmatic turn in the patterns of development aid in order to ensure that aid funding addresses for the need for establishing mechanisms of regulation of migration and remittances (at the local, national and global levels) that are demanded by globalization. Secondly, there is a growing view that migration and development are linked through remittances, and that remittances can be used for productive development ends. The migrant is thus seen as an investor who should direct part of his or her remittances to the productive activities of ongoing co-development projects.

Generally, remittance-focused co-development projects revolve around the debate about the good and bad uses of remittances. These debates normally focus on the way remittances are spent and distinguish productive or unproductive uses of these funds. Private investments are seen as rational and productive uses because they contribute to development and wealth generation through small businesses, etc. On the other hand, private consumption, such as the purchase of land, housing and different goods (clothes, vehicles, electrical appliances, etc), is considered an unproductive use often described as excessive or conspicuous, and without meaningful development impacts.

As Guarnizo has pointed out (2004: 63-64), these arguments have reinforced the idea that remittances must be rechanneled, so both sending and receiving countries and international agencies seeking to "intervene" 
and redirect the final use of remittances, and link them to projects in which they also take part.

The case of co-development between Ecuador and Spain is not an exception, as the projects are based on the premise that migrants often invest their money in a wrong way, and for this reason, the intervention of NGOS has become necessary: "(we did) the typical workshops to manage the remittances in the correct way ...because...they send their money from here, but they don't spend it in what they should spend..." (Aid Worker, IUVE, Madrid, 2007).

One aid worker explained how migrants waste their money on consumption goods and non-productive activities: "...this money was wasted because it was only for consumption, while the country was losing this productive population...so it has to develop all the local areas and all the productive network in the country...then this project is about channeling productive remittances" (Aid Worker, UCMTA, Madrid, 2007).

In this sense, there are two ways of channeling remittances: direct and indirect reorientation. By direct channeling, we mean the transfer of remittances that takes place in accordance with agreements established between remittance agencies and national and international financial institutions. This type of (currently minor) remittance transfer allows people to receive the money directly without having to travel somewhere else in order to get it from a remittance agencies or a commercial bank. This requires agreements with financial entities that possess adequate technology, international presence, and financial capacity to engage in these sorts of monetary transactions. On the other hand, indirect channeling refers to the capture of remittance-derived savings made by families who have received the money from other sources (remittance agencies, private banks, courier, etc.). This is the most common way to send remittances and to link them to social processes, be it through the international cooperation, NGOS, or migrant associations/agencies, as it happens frequently in Mexico.

Regarding the migrant organizations, there are already cases of their participation in projects of co-development and remittances. One example is the Rumiñahui Migrant association and the "Remittances and Development Project", (REDES), as was mentioned previously, and their involvement in advocacy and education around the misuse of remittances by Ecuadorians migrants. In this sense, migrant organizations have incorporated the discourse about the bad use of remittances, as a 
justification of their participation in these projects. The difference with other NGO proposals, is that for migrant associations, the most relevant aspect is that remittances can directly benefit the migrants and their families: "because there are migrants of these areas, and the migrant, who is living here, knows very well his/ her area, and we want to work with him/ her in order to promote that his/ her money was invested there. Because it is not only a matter of development, but co-development, meaning that the migrant and his/ her family from there feel the project as its own project" (Leader Rumiñahui, Madrid, 2007).Thus, remittancefocused co-development projects are about people's empowerment.

\section{TRANSNATIONAL GOVERNANCE OF ECUADORIAN MIGRATION THROUGH CO-DEVELOPMENT}

Co-development projects can be understood as "governance projects" that can be linked with states' strategies of production and reproduction of sovereignty (understood as the power of the state against another external power), and are channeled through the politically mediating role played by the Spanish and Ecuadorian NGO's, and the migrant associations. Thus, in terms of governance, co-development policies and aid have become a means to generate the appropriate conditions to allocate responsibilities, resources and symbolic capital related to migration in a negotiated way between the sending and the receiving countries.

In this sense, the Spanish proposal of co-development represents a specific version of the migration-development nexus from the South of Europe, that exists over the base of discourses, institutions, knowledge, and control forms that could remain underneath of the idea of a "technical co-development". As Foucault remind us, it is necessary to "find how a discourse well formulated in technical terms, conceals and at the same time, it is a political discourse" (Foucault, 1989). Co-development is therefore both a technical and political discourse that presents a specific way of understanding the migration and development nexus, seeing that migration can be instrumental to development objectives, while at the same time, seeking to restrain migration flows to Europe.

The emergence of co-development is related to the increasing migration flows to Spain, in general, and with the political and institutional innovation of Spanish migratory and development aid policies, specifically. Co-development has been used by the Spanish Public Administration as a tool of innovation, modernity, and competition. 
The promotion of development policies by states, including co-development policies, has the effect of locating the position of donor countries in the global arena, and positioning the donor country in the international development agenda. The change in the status of the Spanish state, from that of sending country to receiving one, has contributed to putting it at the same level as other Western European countries. This has fuelled Spanish efforts to contribute to the European project of modernity, in terms of order and rationality, investing in its own, original, and unique model of management of migration flows. Most co-development projects carried out between Ecuador and Spain, between Madrid, Valencia or Murcia and Quito, Cañar, Cuenca, Loja or Guayaquil, were based on these premises. Politically and institutionally, these projects started from the conviction assumed by governments, aid workers, development agencies, and even migrant leaders, that migration could be restrained through development aid.

In this sense, co-development is based on a kind of relationship between the state and civil society. From the perspective of the Spanish state, co-development is seen as an integral, multilateral, and cooperative process, seeking to incorporate a great variety and number of stakeholders, both Ecuadorian and Spanish, and give a role to all of them.

Indeed, the abovementioned "governance projects" of migrants' mobility, are based in the increasing role of NGO's and migrants associations, although which has played a different role in the process. In a broad perspective NGO's will foster co-development induced top-down projects, in the framework of calls for tender and national and local public financial aid. This conforms one of the most relevant features of NGO's: their lack of economic independence from the State in its different regional levels of influence. Therefore, via the public call for tender and direct application for co-development projects, the Spanish State is capable to introduce "at distance" induced political criteria regarding the implementation of a certain migration an development model, as well migration management patterns with the intermediary action of NGO's.

\section{ACKNOWLEDGEMENTS}

This work outlines part of the analysis and conclusions sections of my doctoral thesis thanks to the financing of a Predoctoral Scholarship of the Ministry of Education of Spain (2002-2006). 


\section{NOTES}

1. Meetings on Co-development and Immigration, OPE-SECIPI, September 25-26, 2003, Madrid.

2. Field notes, Madrid, 2003.

3. Ibid.

4. This I was able to check according to repeated testimonies throughout my fieldwork. As a general norm migration was not spoken of outside of families except in those cases of families linked with some organizational process. It was about a topic that was managed in a private, intimate, more hidden environment, than openly declared.

5. Translation Note: "Migrant House".

6. Translation Note: "Agreement of collaboration among the Quito City Council, the Hispanic-Ecuadorian Rumiñahui Association and the Movement by Peace, Disarmament and Freedom (MPDL, Spanish).

7. Field notes, Quito, 2005.

8. Translation Note: Union of Madrid Cooperatives of Associated Work.

9. Co-development Agreement signing between the AECID and ACSUD- Las Segovias, Valencia: 'Agreement of cooperation to foster the use of remittances as a tool of human, social and economic development, in the Ecuadorian communities of the provinces of Loja and Zamora linked to the Confederation of Indigenous Nationalities in Ecuador (CONAIE). All of this, in connection with communities from these areas, that live in the Valencia and Alicante provinces. Ecuador'.

\section{REFERENCES}

Abad, L.V.

2008 "Emigración y desarrollo. Un enfoque desde las condiciones iniciales", in J. García Roca and J. Lacomba, La Inmigración en la Sociedad Española. Una Radiografía Multidisciplinar, Bellatera, Barcelona: 717-750 (in Spanish).

Aja, E.

2006 "La evolución de la normativa sobre inmigración”, in E. Aja and J. Arango, Veinte años de Inmigración en España. Perspectivas Jurídicas y Sociológica (1985-2004), Fundació CIDOB, Barcelona: 17-46 (in Spanish).

Aubarell, G., H. Oliván and X. Aragall

2003 "Inmigración y codesarrollo en España”, in G. Aubarell (Ed.), Perspectivas de la Inmigración en España. Una Aproximación Desde el Territorio, Icaria, Barcelona: 393-414 (in Spanish).

Brettel, C., and J. Hollifield

2000 Migration Theory. Talking across disciplines, Routledge, London and New York: 137-187. 
Burawoy, M., J.A. Blum, S. George, et al.

2000 Global Ethnography: Forces, Connections and Imaginations in a Postmodern World, University of California Press, Berkley.

Carballo, M.

2006 "Migraciones y codesarrollo", Revista Española de Desarrollo y Cooperación, $n^{o}$ 17, invierno, Madrid: 115-117 (in Spanish).

Carballo, M., and E. Echart

2007 Migraciones y Desarrollo. Estrategias de Acción en el Sahel Occidental, IUDC-UCM/FIAPP, Madrid (in Spanish).

Cortés, A.

2004 La Emergencia del Codesarrollo: Una Perspectiva Transnacional, Actas del $4^{\circ}$ Congreso de Inmigración a España, Gerona.

2005 "La experiencia del codesarrollo entre Ecuador y España: una aproximación a un transnacionalismo desde el medio", in G. Herrera, et al. (Eds), La Migración Ecuatoriana: Transnacionalismo, Redes e Identidades, FLACSO Ecuador y Plan Migración, Comunicación y Desarrollo, Quito: 253-277.

2009a "Los antecedentes políticos del codesarrollo: la reinvención del vínculo entre la migración y el desarrollo en el sur de Europa", in F. Checa and et al. (Eds), Las Migraciones en el Mundo, Desafios y Esperanzas, Icaria Antracyt, Barcelona: 55-95.

2009b "La migración ecuatoriana en el codesarrollo: ¿hacia una gobernanza transnacional?" in A. Cortés and A. Torres (Eds), Codesarrollo en los Andes: Contextos y Actores para una Acción Transnacional, FLACSO - Instituto Universitario de Migraciones, Etnicidad y Desarrollo (IMEDES) - Ayuntamiento de Madrid, Quito (in Spanish).

2010 Estados, Cooperación para el Desarrollo y Migración: El Caso del Codesarrollo entre Ecuador y España, $\mathrm{PhD}$ dissertation, Departamento de Antropología Social, Univesidad Autónoma de Madrid, Madrid, (in Spanish).

Cortes, A., M. Fernández and A. Sanmartin

2007 "La práctica del codesarrollo en España", V Congreso sobre la Inmigración en España, Migraciones y Desarrollo, Valencia, págs. $1-15$.

De Haas, $\mathrm{H}$.

2006 Engaging Diasporas. How Governments and Development Agencies can Support Diaspora Involvement in the Development of Origin Countries, International Migration Institute, Oxford.

Diario El Comercio

2004 "El acuerdo migratorio con España fracasó", 17 June, Quito. (in Spanish).

Echeverri, M., R. Ibáñez and M. Ortí

2007 El Codesarrollo desde la Perspectiva de la Población Inmigrante. Una Aproximación a las Representaciones Sociales y Discursos Sobre el Desarrollo de los Migrantes Ecuatorianos y Marroquies en Madrid, Acsur-Las Segovias, Madrid (in Spanish). 
Eguren, J.

2004 "La configuración de una comunidad marroquí rifeña de índole transnacional entre Marruecos y España”, 4o Congreso Nacional de la Inmigración a España, Girona.

2007 "La configuración de la etnicidad a nivel transnacional de los rifeños bereberes del Norte de Marruecos", 5o Congreso de la Inmigración a España, "Migraciones y Desarrollo Humano", Valencia (in Spanish).

Gil, S.

2004 "Gobernando a distancia: el papel de las ONG en la gestión de la integración de inmigrantes", IV Congreso de la Inmigración a España, Girona (in Spanish).

Giménez, C.

2005 ¿Qué es el Codesarrollo? Expectativas, Concepciones, y Escenarios de Futuro, CIDEAL, Madrid (in Spanish).

Giménez, C., J. Martínez, et al.

2006 El Codesarrollo en España: Protagonistas, Discursos y Experiencias, Los Libros de la Catarata, Madrid (in Spanish).

Gómez Gil, C.

2008 Potencialidades y Limitaciones del Codesarrollo, Bakeaz, Bilbao (in Spanish).

Guarnizo, L. E.

2004 "Aspectos económicos del vivir transnacional", in A. Escrivá and Gupta, A. N. Ribas (Eds), Migración y Desarrollo, CSIC, Córdoba (in Spanish).

1998 Postcolonial Developments: Agriculture in the Making of Modern India, Duke University Press, London.

Izquierdo, A.

2002 "Panorama de la inmigración en España al alba del siglo XXI", Mediterráneo Económico, 1: 247-264 (in Spanish).

Jokisch, B., and J. Pribilsky

2002 "Economic crisis and the 'new emigration' from Ecuador", International Migration, 40(4): 75-101.

Kastoryano, R.

2000 "Immigration, communautés transnacionales et citoyenneté", Revue Internationale des Sciences Sociales, 165: 353-359. (in Spanish).

Labelle, $\mathrm{M}$.

2002 "Re-reading citizenship and the transnational practices of immigrants" May, Centre d'études et de recherches internationales,

Lacomba, J. Paris, available at http://www.ceri-science-po.org.

2002 "Los efectos de la emigración sobre el desarrollo. El caso de las migraciones en Marruecos", Tercer Congreso de la Inmigración en España, Granada (in Spanish).

2004 Migraciones y Desarrollo en Marruecos, Los Libros de la Catarata, Madrid (in Spanish). 
Laubenthal, B.

2005 "La emergencia de las protestas de inmigrantes sin papeles en España: el caso de la Región de Murcia", in A. Pedreño and M. Hernández (Eds.), La Condición Inmigrante, Universidad de Murcia, Murcia: 159-173 (in Spanish).

Levitt, P., and N. Glick Schiller

2003 "Transnational perspectives on migration: conceptualizing simultaneity", Working Paper 03, Centre for migration and development, Princeton University, Princeton.

Levitt, P., and R. de la Dehesa

2003 "Transnational migration and the redefinition of the state: variations and explanations", Ethnic and Racial Studies, 26(4): 587-611.

López Sala, A.

2002 "Los retos políticos de la inmigración”, Isegoría, 26: 85-105. (in Spanish).

Malgesini, G.

2007 ¿Qué es el Codesarrollo y Cómo Participar en él?, CIDEAL, Madrid (in Spanish).

Marcus, G.

2001 "Etnografía en/ del sistema mundo. El surgimiento de la etnografía multilocal", Alteridades, 11(22): 111-127. (in Spanish).

Marín, I.

2004 "Emigración, pobreza y cooperación al desarrollo en el Norte de Marruecos: discursos y realidades entre las dos orillas", Actas del $4^{\circ}$ Congreso sobre la inmigración en España, Girona (in Spanish).

Martín, E., A. Castaño, Assumpta Sabuco i Cantó et al.

2008 El Papel de las Mujeres Inmigrantes en el Desarrollo de sus Localidades de Origen: el Caso de las Marroquies y las Ecuatorianas, Instituto de la Mujer, Ministerio de Igualdad, Madrid (in Spanish).

Ministerio de Asuntos Exteriores y Cooperación (Spain)

2009 "Plan Director de la Cooperación Española 2009-2012”, Ministerio de Asuntos Exteriores y Cooperación, Madrid (in Spanish).

Morris, L.

1998 "Governing at a distance: the elaboration of controls in British immigration", International Migration Review, 22(4): 949-73.

Østergaard-Nielsen, E.K.

2003 "The politics of migrants' transnational political practices", International Migration Review, 37: 760-86.

Padilla, B., and N. Moraes

2007 "La vinculación de los Estados latinoamericanos con sus diásporas: el caso de Brasil y Uruguay", 5 Congreso sobre la Inmigración a España, "Migraciones y Desarrollo Humano", Valencia (in Spanish). 
Pajares, M.

2007 "La Red Social en los procesos de inserción laboral de los inmigrantes rumanos", 50 Congreso sobre la Inmigración a España, "Migraciones y Desarrollo Humano", Valencia (in Spanish).

Pedone, C.

2004 "Tú siempre jalas a los tuyos. Las cadenas y redes migratorias de las familias ecuatorianas hacia España", $\mathrm{PhD}$ dissertation, Departamento de Geografía, Universidad Autónoma de Barcelona,

Peró, D. Barcelona, (in Spanish).

2005 "Immigrants and the politics of governance in Barcelona", Working Paper No. 19, Centre on Migration, Policy and Society,

Portes, A. University of Oxford, Oxford.

2007 "Migration, development, and segmented assimilation: a conceptual review of the evidence", The Annals of the American Academy of Political and Social Science, 610: 98-118.

Ramón Chornet, C.

1999 "Nuevas orientaciones de la política de ayuda y cooperación al desarrollo de la Unión Europea: la propuesta de codesarrollo", in Cursos de Derecho Internacional de Vitoria/Gasteiz 1998, Tecnos, Madrid (in Spanish).

2002 "Inmigración y codesarrollo. Razones de un cambio de estrategia en el 2002" in Tiempos de Paz, no 66, Movimiento por la Paz, el Desarme y la Libertad, Madrid: 29-37 (in Spanish).

2005 "El vínculo entre estrategias de codesarrollo y políticas de inmigración en el Mediterráneo" in Migracions i Cooperació pel desenvolupament a la Mediterránea, IEMED, Barcelona (in

Rose, N. Spanish).

1997 "El gobierno en las democracias liberales 'avanzadas': del liberalismo al neoliberalismo", Archipiélago, 29: 25-40. (in Spanish).

Sanmartin, A.

2009 El codesarrollo en España: un análisis de la implicación de los migrantes, $\mathrm{PhD}$ dissertation, Instituto Ortega y Gasset, Universidad Complutense de Madrid, Madrid, (in Spanish).

Santos, B., and C. Rodríguez

2007 "El derecho, la política y lo subalterno en la globalización contrahegemónica" in B. Santos and C. Rodríguez (Eds.), El Derecho y la Globalización Ddesde Abajo: Hacia una Legalidad Cosmopolita, Anthropos Editorial, Barcelona: 7-28 (in Spanish).

Sanz, J.

2009 Entre "cumplir" y "hacer cosas". Estrategias Económicas y Simbolismo en el uso de las Remesas de la Migración Ecuatoriana en España, $\mathrm{PhD}$ dissertation, Departamento de Antropología Social, Universidad Rovira i Virgili, Tarragona (in Spanish). 
Sassen, S.

2001 Perdiendo el control, Bellaterra, Barcelona (in Spanish).

Smith, M.P.

2001 Transnational Urbanism, Locating globalization, Blackwell, Oxford.

2005 "Transnational urbanism revisited", Journal of Ethnic and Migration Studies, 31(2): 235-244.

Sørensen, N.N., and K. Fog

2002 Life and Livelihood in a Globalizing World, Routledge, London.

Vertovec, S.

2001 "Transnationalism and identity", Journal of Ethnic and Migration Studies, 27(4): 573-582. 